\title{
A Translation Dictionary of Phrasal Verbs: An Ongoing Project
}

\author{
Mohamed Helmy Heliel, Alexandria University, Alexandria, Egypt
}

\begin{abstract}
The paper centres on a plan for an English-Arabic phrasal verb dictionary for Arab trainee translators. Such a dictionary answers a pressing need. It is not a bilingual dictionary but a translation one. This requires special lexicographical treatment as regards selection of headwords, structure of phrasal verbs, literal and figurative usage, definitions, synonyms, illustrative examples, relatedness of meaning, order of senses, collocations and discriminated equivalents.
\end{abstract}

Keywords: PHRASAL VERBS, TRANSLATION DIFFICULTIES, PHRASAL VERB TRANSLATION DICTIONARY, HEADWORDS, DERIVATIVES, FIGURATIVE SENSE, STRUCTURE, DEFINITIONS, SYNONYMS, MEANING RELATEDNESS, SENSES, COLLOCATIONS

Opsomming: 'n Vertalende woordeboek van frasewerkwoorde: 'n voortgesette projek. Hierdie artikel handel oor die beplanning van 'n Engels-Arabiese woordeboek van frasewerkwoorde vir Arabiese leerlingvertalers. So 'n woordeboek voorsien in 'n dringende behoefte. Dit is nie 'n tweetalige woordeboek nie, maar 'n vertalende woordeboek. Dit vereis spesiale leksikografiese hantering betreffende die seleksie van trefwoorde, struktuur van frasewerkwoorde, letterlike en figuurlike gebruik, definisies, sinonieme, voorbeeldmateriaal, betekenisverwantskap, volgorde van betekenisonderskeidings, kollokasies en onderskeidende ekwivalente.

Sleutelwoorde: FRASEWERKWOORDE, VERTALINGSPROBLEME, VERTALENDE WOORDEBOEK VAN FRASEWERKWOORDE, TREFWOORDE, AFLEIDINGS, FIGUURLIKE BETEKENIS, STRUKTUUR, DEFINISIES, SINONIEME, BETEKENISVERWANTSKAP, BETEKENISONDERSKEIDINGS, KOLLOKASIES

\section{Introduction}

Under current teaching conditions of English as a foreign language, Egyptian students in the Department of English Language and Translation at Alexandria University have difficulties with English phrasal verbs. Though phrasal verbs are to some extent consistent in their behaviour and are now more teachable, as reflected in some excellent textbooks such as Britten and Dellar (1991), Murphy (1983) and Goodale (1993), our students who are native speakers of Arabic find them difficult to translate.

Phrasal verbs are by no means confined, as is claimed, solely to spoken English. Through our translation teaching experience of mass media texts, phrasal verbs proved to be of one of the major problems. To illustrate, we quote 
the following ten sentences that the students were asked to translate from an English newspaper:

(a) Further gains would ward off any quick recognition by the outside world of Aden regime.

(b) Heavy rebel guns opened up 15 minutes after UN envoy left Kigali.

(c) Britain yesterday brushed off positive signals from the IRA political leadership.

(d) Mortar battles picked up despite a 36-hour cease-fire.

(e) Residents had been called up to help regular troops retain control of provinces.

(f) He was pressing for further quick military gains to head off foreign recognition of the breakaway state.

(g) Poland to speed up privatisation.

(h) The suicide bomber blew himself up.

(i) The Cosmos 2281 satellite blasted off aboard a Cyclon-3 booster rocket on a military mission ...

(j) The fall-off in demand was also evident at Banbury cattle market in central England.

It can safely be said that many of the phrasal verbs are perfectly acceptable in formal writing. As a matter of fact, they supply meanings which are not otherwise concisely expressed.

From translation teaching experience in the Department of English Language and Translation we realised that the learning of phrasal verbs at school is generally not satisfactory. The problems encountered in learning and translating phrasal verbs could be summed up in the following points:

(a) The difficulty of translating word combinations whose meaning bears little or no relation to the individual words of which they are composed.

(b) Confusion between forms of phrasal verbs and their meanings.

(c) The intricate network of relations that a phrasal verb forms with other words whether collocationally or colligationally.

(d) Difficulty of finding the appropriate Arabic equivalents to phrasal verbs due to lack of accurate understanding of their meaning.

(e) The phrasal verb may not only be polysemic in having both an idiomatic and a non-idiomatic use, it may well be polysemic in having more than one idiomatic or figurative use e.g. (a) put up (for the night) (b) put up (a fight).

(f) Phrasal verbs are by no means static, they move from colloquial to more formal contexts: mass media, radio news broadcasts, etc. and are always on the increase. 
(g) The phrasal verb is a feature typical of English and not of Arabic. In Arabic the verb may govern (a) the accusative of a noun, or (b) a preposition with the genitive of a noun, e.g.:

$\begin{array}{lll}\text { lahiqa } & \text { bi- } & \text { 'abiihi } \\ \text { caught up- } & \text { with- } & \text { his father }\end{array}$

which takes the place of the accusative and gives greater precision and accuracy to the expression (Wright 1967: 44).

In Arabic, the verb retains most of its meaning and the preposition retains some degree of its literal or 'physical' meaning, although some combinations may be used figuratively. In English the range is far more complex: the meaning may be totally unpredictable and the verb and the particle fused.

(h) The freedom with which derivatives form phrasal verbs appear and the semantic specialisation that goes with them (e.g., falling off in theatre attendances).

(i) The unsatisfactory lexicographical treatment of phrasal verbs in EnglishArabic general and specialized dictionaries (Heliel 1995).

Hence there is a pressing need for an English-Arabic dictionary of phrasal verbs which would serve as a translatory dictionary.

\section{Dictionaries of English-Arabic phrasal verbs}

The first attempt is Mazhar's (1949) Dictionary of Sentences and Idioms which contains a mixture of phrasal verbs and idiomatic expressions including verbs, nouns and adjectives as headwords. It is limited in scope. The target group is that of primary and secondary school levels of education. The second attempt is A Dictionary of English Idioms (1985) where some phrasal verbs are included together with their idiomatic expressions.

The only dictionaries devoted solely to phrasal verbs are:

(a) Khalaili's (1979) English Phrasal Verbs in Arabic which covers 162 pages and treats only a limited number of 44 phrasal verbs. It is by no means "comprehensive or academically rigorous" (p.2). The targeted audience are intermediate learners.

(b) Saadat and Naser's (1993) Dictionary of Phrasal Verbs is the only mediumsized specialized dictionary of English-Arabic phrasal verbs available. The target group is not specified. On the whole, the dictionary is far from being a help to the translator. In the main, it provides us with literal, non-discriminated decontextualised and thus meaningless Arabic equivalents. In many cases, the Arabic equivalents are rather odd para- 
phrases or literal translations of the definitions given in an English monolingual dictionary. It is not clear on what basis it has incorporated some phrasal verbs and excluded others. The Arabic used in the dictionary is far from being accepted.

With all the difficulties encountered by the Arab translators and the present state of dictionaries of phrasal verbs in mind, we started planning for a new English-Arabic dictionary of phrasal verbs.

\section{A translation dictionary}

The proposed dictionary is by no means a bilingual one that confines itself to Arabic equivalents of English phrasal verbs. It is a dictionary which aims at helping the translator understand the phrasal verbs and stimulate him to find the Arabic equivalents that will fit in with the text he is translating. To achieve this goal the English and Arabic divisions should be carefully planned and worded and this is what distinguishes it from other English-Arabic dictionaries. The following are the lexicographical principles that will be adopted in the dictionary.

\section{Headwords}

Frequency of use should be the overriding criterion for selection. In this respect, it has to be noted that:

(a) The Collins COBUILD Dictionary (1989) lists over 3000 combinations of phrasal verbs explaining over five and a half thousand different meanings. It claims that these combinations are the ones in common use in everyday modern English. What lends support to this statement is the fact that the dictionary is based on a detailed computational study of the Birmingham collection of English texts. In the absence of reliable statistical studies the Collins COBUILD will be used as a guide.

(b) The Particles Index in Collins COBUILD (1989) is an extensive guide to the way in which particles are used in English phrasal verbs. It also gives the actual number of occurrences of each particle which will be of interest in the selection of the headwords for our dictionary. It will help us determine which phrasal verbs to choose and focus on.

According to Collins COBUILD (1989: 449-491) the commonest particles are up, out, off, in, on, and down, in descending order of frequency. Up (482) and out (410) are extremely common comprising (28\%) of the phrasal verbs listed in the COBUILD dictionary. They are followed by off, 
in, on, down, away, into, over, around as is clear from the COBUILD computer data study:

$\begin{array}{llll}\text { aback } & 001 & \text { forth } & 011 \\ \text { about } & 088 & \text { forward } & 010 \\ \text { above } & 005 & \text { from } & 123 \\ \text { across } & 006 & \text { in } & 209 \\ \text { after } & 015 & \text { into } & 112 \\ \text { against } & 030 & \text { off } & 233 \\ \text { ahead } & 014 & \text { on } & 198 \\ \text { along } & 023 & \text { onto } & 012 \\ \text { among } & 004 & \text { out } & 410 \\ \text { apart } & 010 & \text { over } & 111 \\ \text { around } & 104 & \text { round } & 058 \\ \text { as } & 008 & \text { through } & 059 \\ \text { aside } & 015 & \text { to } & 064 \\ \text { at } & 045 & \text { together } & 022 \\ \text { away } & 134 & \text { towárds } & 011 \\ \text { back } & 083 & \text { under } & 009 \\ \text { before } & 005 & \text { up } & 482 \\ \text { behind } & 010 & \text { upon } & 083 \\ \text { by } & 022 & \text { with } & 056 \\ \text { down } & 191 & & \\ \text { for } & 063 & & \end{array}$

(c) Emphasis should also be placed on certain verbs (i.e. be, come, get, look, put, take, turn, work) which seem "to combine more frequently with particles than other verbs. The more particles with which a verb combined, the wider the range of meanings for each form." (Ryan 1984:20).

(d) Usually, these function words (out, off, on, ...etc.) do not have consistent meanings in the phrasal verbs of which they are a part. There are, however, a few 'families', so to speak, of phrasal verbs in which the function words carry a fairly consistent meaning. These families require special lexicographical treatment in formulating their definitions, indicating the concepts to which they refer and hence helping the translator find the appropriate way of expressing them in Arabic. The proposed dictionary should benefit from:

(a) The Particles Index in Collins COBUILD (1989: 450-491)

(b) Harrap's English Verbs (1989: 83-89) 


\subsection{Derived forms}

Any noun, adjective or modifier formed from a phrasal verb should be entered under the phrasal verb headword. British English, it has to be noted, absorbs many nominalised forms:

(a) nouns indicating activities: e.g. blast-off, sit-in

(b) gerunds: beating up, dressing down

(c) past participles used as nouns, e.g. leftover, dugout

Some of these forms may enter a compound, e.g. breakdown truck, breakaway movement. The freedom with which these noun forms appear and the semantic load they carry justifies incorporating them. Such forms, though quite common in newspaper English, for example, are missing from our English-Arabic dictionaries. Mention should be made of the fact that the derived nouns from phrasal verbs do not have all the senses of the phrasal verb. Only nouns derived with the same sense of the verb should be included together with illustrative examples and Arabic equivalents. Some of these nouns, however, may have a particular sense which is not there in the verb, e.g.:
blow out (v)
1. (a flame or a fire) it stops burning
2. (a tyre) burst
3. (gas) escaping
blow out (n)
1. tyre
2. escape of gas
3. a big expensive meal or large social occasion

Such a sense (no. 3) will not be included.

\section{Structure}

Stating that the structure of a phrasal verb is either $v+$ prep or $v+a d v$, as is common in some dictionaries (Saadat and Naser 1993), does not help the translator. However, since meaning varies according to the different types of structures in which the phrasal verb occurs, it should be clearly stated whether the phrasal verb is transitive or intransitive. In the first case both the subject and the object collocate should be indicated and in the second only the subject collocate. The translator should correlate difference in form with difference in meaning. 


\section{Meaning}

The literal meaning of phrasal verbs should be given to relate it to the idiomatic or figurative one. The proposed dictionary will comprise:

(a) Idiomatic phrasal verbs, i.e., idiomatic combinations where the meanings of the separate parts tell us little or nothing about the meaning of the whole.

(b) If the verbal combination has a normal or literal meaning as well as an idiomatic or figurative one, then both are listed. The compilers of Collins Dictionary of Phrasal Verbs and their Idioms (1974) argue that "differences of meaning occur within a continuum of meaning beginning with the simple verb + particle and ranging through to the more opaque idioms" (p.6).

The following types of phrasal verbs are not included:

(a) Idioms which are connected with phrasal verbs, e.g. to pull in one's horns. These should be entered in a dictionary of idioms.

(b) Phrasal verbs such as depend on, depart from where the verb, though it always has the same meaning, can only be used with a certain preposition when used in a combination. In such cases the information value of the preposition is either reduced or nil. It is no more than a dummy element (Rastall, 1994). These non-idiomatic or literal prepositional verbs, which simply combine the meanings of their parts, are excluded.

However, there are many phrasal verbs which are neither fully idiomatic nor fully literal. The guide for selection in these cases will be comprehensibility.

From experience we realised that trainee translators have difficulties with:

(a) Verbs of movement with prepositions of direction, e.g.

(i) The crowd pressed in through the cordon of guards.

(ii) I need her over to help me with the children.

Jowett's (1951) words about the English language ring quite true in the translation classroom:

"It is indeed a language in which wè call upon simple verbs concerned with acts, motions and attitudes of the body to express a vast range of human activities. We tend to think in terms of muscular and tactile sensation, to try to express sensuous reality, and so to employ kinaesthetic rather than visual imagery. Thus we go for an opponent when we attack 
him, we feel run down when we are nervously exhausted, we fall out when we quarrel ..." (Jowett 1951: 155).

(b) Phrasal verbs which are used figuratively. Such phrasal verbs, though by far the most difficult to translate (Heliel 1995), are missing from both general and specialized English-Arabic dictionaries of phrasal verbs, e.g.:

(i) To patch things up is literal when it refers to mending with patches with the Arabic equivalent yartuqu.

(ii) To patch up is figurative when it refers to settling differences with the Arabic equivalent yusawwii.

Both kinds of verbs will receive particular attention.

\section{Definition}

In a translation-oriented dictionary like ours, accurate and detailed definitions in English are badly needed and are important for the understanding of the phrasal verb in its language context and hence for translating it. An all-embracing definition will provide the translator with an important clue to the meaning which is reinforced by synonyms and illustrative examples. Unsatisfactory definitions together with deficient illustrative examples detract from the value of the English section in the dictionary and we will be left with the inadequate decontextualised Arabic equivalents which are of no use to the translator. Compare (a) and (b), (c) and (d):

(a) talk away: force to go away by talking. I'm afraid you won't talk this problem away. He can't talk away his enormous debts.

(b) talk away: to get rid of a feeling with words. Stay with the child as he goes into hospital, you may be able to talk his fears away.

(c) live down: survive, manage to forget. You'll never live it down. It will be difficult to live down this humiliation.

(d) live down: If you are unable to live down a mistake, failure, or foolish action, you are unable to make people forget that you did it. The story of a young girl who finds it impossible to live down her past.

The italicized words in (b) and (d) above are important details for conveying the meaning to the translator. Short renderings of phrasal verbs (example (c) above) may lead to wrong Arabic equivalents. The definition of a phrasal verb especially a figurative one should be carefully worded as that of the one-word entry in a monolingual dictionary, not to be confined to the label figurative. The following example (b), for lack of definition, proved to be difficult to understand: 
siphon off remove or transfer by means of a siphon.

(a) (lit.) Someone has siphoned off my petrol.

(b) (fig.) The department is good at siphoning off funds from one area to another. They have siphoned the money off for their own use.

\subsection{Synonyms}

In our proposed dictionary we will make use of all that would help the translator get a better understanding of the phrasal verb. Though synonymy is a relative concept (Cornell 1985: 274) and synonyms differ in collocations, adding them to the definition will be of some help to the translator., e.g.

die away $\longrightarrow$ definition + (same as fade).

Among dictionaries that proved quite useful as sources for synonyms of phrasal verbs are: The Reader's Digest Oxford Wordfinder (1993), The Merriam-Webster Concise School and Office Thesaurus (1991) and The Concise Oxford Thesaurus (1995).

\section{Illustrative examples}

Just like synonyms, illustrative examples would help reinforce the meaning by showing how the phrasal verb is actually used in an appropriate context with the words that normally collocate with it. It is important that illustrative examples should justify their existence. Compare (a) and (b), (c) and (d):

(a) walk out on. Don't walk out on me. You can't just walk out on us like this.

(b) It's the first time my husband's walked out on me.

(c) wink at. Can't you wink at what they are doing.

(d) Many of the teachers wink at the boys' secret smoking.

In (a) and (c) there are no clues to the nature of the collocate which to a large extent determines the Arabic equivalent. In (b) and (d) the wife (implicit object), teachers and smoking (subject and object) do determine the Arabic equivalents to the phrasal verb.

The decision whether to stick to short phrases and minimal contexts or to use full-length sentences for illustration was difficult to make. It was found out that both approaches are required but for different entries: 
(a) Example of a phrasal verb with a sentence as an example: put through. I rang the bank and asked to be put through to the overseas department.

(b) Example of a phrasal verb with a minimal context, just a collocate: put forward (idea, suggestion, plan).

In (a) it is thought advisable to use a sentence to reinforce the definition, and convey the idea of connecting two persons on the telephone. In (b) what is put forward, i.e. the collocate, is what is needed.

\section{Relatedness of meaning and order of senses}

In his attempt to understand the phrasal verb, the translator makes use of the definition, the synonyms and the example sentences provided. Thus the English entry should be a closely-knit unit. Figurative meaning should follow the literal one and the order of senses should be determined by logical relatedness not frequency of occurrence. Compare the following entries chosen from two different dictionaries:

(1) put aside (a) see put (b) (fig. abandon) He put aside his anger. (c) (save) She has managed to put aside a little money.

(2) You put something aside a. when you separate it from other things for some purpose. She unpacked her baggage and put aside things to be taken upstairs $\mathbf{b}$. When you save it for future. I'd been putting money aside for my holiday. [same as save] c. When you abandon it. Publishers should put aside their prejudices [same as discard].

\section{Arabic equivalents}

The meaning of a lexical item which is given in a dictionary entry must be regarded as Jackson (1988) rightly says; "'potential", a distillation of the essentials awaiting actualisation in a particular linguistic and situational context". Thus the one-word equivalent in Arabic may not be helpful or might not be the appropriate translation. The translator should be provided with a full range of possibilities in the English section (definition, explanation, synonyms, example sentences, collocates) and a number of Arabic synonymous equivalents whether words or phrases from which the translator will be free to choose, e.g.

waste away to become weak and ill gradually. [same as grow weak, wither]. Since my aunt's disease, she's been wasting away

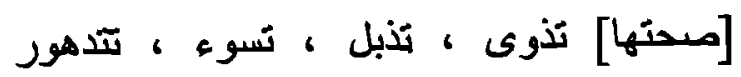

[sihḥatuhaa] tadhwaa, tadhbulu, tasuu'u, tatadahwaru. 
It also happens that the translator may select a word in the mother tongue which is not amongst the equivalents given but it fits in perfectly with the text he is translating. In this case the English entry and the Arabic synonymous equivalents with the collocates shown between square brackets will serve as stimulants for the right translation.

One of the major weaknesses of English-Arabic bilingual dictionaries is their non-discriminated Arabic equivalents or mere Arabic paraphrases, e.g.

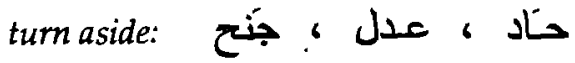

$$
\begin{aligned}
& \text { [ḥaada, 'adala, dzanaḥa] }
\end{aligned}
$$

The Arabic decontextualized verbs are of no help to the translator. They even lack the prepositions which accompany them and specify their meanings in Arabic.

\section{Collocations}

Phrasal verbs may be regarded as not collocations but a verb sub-type that occurs within a collocation. There are frequently strong collocational associations between phrasal verbs and other words that determine the Arabic equivalent (Heliel, 1995). Whether in the English or Arabic section collocations should be indicated, e.g. fight back (tears/ emotions/ doubts/ fears/ desires), where for each collocation there is a particular Arabic verb equivalent.

Whether short phrases or full-length sentences are used in the English entry, what is extremely important is focusing on the collocate (subject, object or both), not translating the example sentence, e.g.,

tone down (radio / intensity of colours )

$$
\text { يخفض صوت [الر اديو] ، بخفف من [حدة اللون] }
$$

yukhaffifu, șawta [al-raadyoo] yukhaffifu min [al-lawn]

\section{Conclusions}

An English-Arabic dictionary of phrasal verbs is an indispensable tool for the Arab translator. In such a translation-oriented dictionary, certain features should be brought into focus:

(i) On the English side

(a) The morphological and syntactic aspects of the phrasal verb. 
(b) Selection which should be based on the frequency of use in the language.

(c) Accurate and detailed definitions including synonymous equivalents and illustrative examples.

(d) The network of relations the phrasal verb forms with other words (collocations).

(e) Order of senses and logical relatedness of meaning.

(ii) On the Arabic side:

(a) Arabic equivalents with synonyms to help the translator choose from amongst them, the one that fits in well with the text he is translating.

(b) The collocates that go with the phrasal verb and determine its meaning.

\section{References}

Britten, Donald and Gwendolyn Dellar. 1991'. Using Phrasal Verbs. London: Prentice Hall. Comell, Alan. 1985. Realistic Goals in Teaching and Learning Phrasal Verbs. IRAL 23 (4): $269-280$. A Dictionary of English Idioms: English-Arabic. 1985. (Compiled by a team of university teachers of English.) Beirut: Librairie du Liban.

Goldie, Jane. 1989. Harrap's English Verbs. London: Harrap.

Goodale, Malcolm. 1993, Collins COBUILD Phrasal Verbs Workbook. London: Harper Collins.

Heliel, M.H. 1995. Towards a Dictionary of English-Arabic Phrasal Verbs for the Arab Translator. A paper presented at the 2nd International Maastricht-Lodz Duo Colloquium on "Translation and Meaning", Lodz, 22-24 September 1995.

Jackson, Howard. 1988. Words and their Meaning London: Longman.

Jowett, W.P. 1951. On Phrasal Verbs. ELT 5(6) : 152-157.

Khalaili, K. 1979. English Phrasal Verbs in Arabic. London: Hodder and Stoughton.

Kirkpatrick, Betty. 1995. The Concise Oxford Thesaurus. Oxford: Oxford University Press.

Mazhar, I. 1949. A Dictionary of Sentences and ldioms: English-Arabic. Cairo: The Renaissance Bookshop.

McArthur, Tom and Beryl Atkins. 1974. Dictionary of English Phrasal Verbs and their Idioms. London: Collins.

The Merriam-Webster Concise School and Office Thesaurus. 1991. Springfield: Merriam-Webster. Murphy, M.J. 1983. Understanding Phrasal Verbs. London: Hulton.

Rastall, P. 1994. The Prepositional Flux. IRAL 32 (3) : 229-231.

Ryan, S.M. 1984. The Frequency of Phrasal Verbs in Spoken American English. Los Angeles: University of Califomia, MA thesis.

Saadat, A.E and K.A. Naser. 1993. Dictionary of Phrasal Verbs: English-Arabic. Ryadh: Mars.

Sinclair, J. et al. 1989. Collins COBULD Dictionary of Phrasal Verbs. London: Collins.

Tillock, Sarah. (Ed.). 1993. The Reader's Digest Oxford Wordfinder. Oxford: Clarendon Press.

Wright, W. 1967. A Grammar of the Arabic Language. Cambridge: Cambridge University Press. 